\title{
PHYTOCHEMICAL EVALUATION OF WILD AND CULTIVATED PEPPER (Capsicum annuum L. and C. pubescens Ruiz \& Pav.) FROM OAXACA, MEXICO
}

\author{
Araceli Minerva Vera-Guzmán ${ }^{1}$, José Luis Chávez-Servia ${ }^{1 *}$, José Cruz Carrillo-Rodríguez², \\ and Mercedes G. López ${ }^{3}$
}

Reports of the last decade show that some types of food and spices included in the human diet, such as pepper (Capsicum annuum L.) can have a positive effect on human health. The Mexican pepper germplasm is poorly documented with regard to variety and the amount of phytochemical compounds that it contains. In the present study, the variation of phytochemical compounds was evaluated in nine fruit variants (morphotypes) of wild and cultivated pepper grown in Oaxaca. ANOVA detected significant differences among pepper morphotypes and ripeness stages of fruits; vitamin C, total phenols, flavonoids, $\beta$-carotene, coordinated chromatic of color, and capsaicinoids. The highest values of vitamin $\mathrm{C}$ were found in 'Tabaquero', 'Güero' and 'Costeño' morphotypes (151.6 to $183.2 \mathrm{mg} 100 \mathrm{~g}^{-1}$ ). With regard to total phenols and flavonoids, 'Piquín' and 'Solterito' had the highest levels. Coordinates of color $\mathrm{a}^{*}$ and $\mathrm{b}^{*}$, and chroma presented a positive correlation with phenol and flavonoid contents. The evaluated morphotypes differed in capsaicin and dihydrocapsaicin; $C$. annuum had higher capsaicin content (4.9 to $142 \mu \mathrm{g} \mathrm{mL}^{-1}$ ) than dihydrocapsaicin (1.5 to $\left.65.5 \mu \mathrm{g} \mathrm{mL}^{-1}\right)$ and $C$. pubescens Ruiz \& Pav. showed the opposite pattern.

Key words: Capsaicionids, Capsicum annuum, carotenoids, phenols, flavonoids, vitamin C.

$\mathrm{M}$ exico is the center of origin and diversity of Capsicum annuum $\mathrm{L}$., it is mainly found in tropical and subtropical regions which have a high genetic diversity within and among wild botanical varieties; for example in C. annuиm var. aviculare, $C$. annuиm $\mathrm{L}$. var. annuum and C. annuum var. glabriusculum (Dunal) Heiser \& Pickersgill, which also exchange genes with landraces grown in backyards (Eshbaugh, 1980; HernándezVerdugo et al., 2001; Votava et al., 2002). Capsicum pubescens Ruiz \& Pav. and C. chinense Jacq. species were added to this historical genetic legacy of peppers that have been part of the Mexican diet for at least a century (Smith and Heiser, 1957; Muñoz and Pinto, 1966; Vela, 2009). According to the findings of Perry and Flannery (2007) at the Guilá Naquitz caves in Oaxaca, this State is one of the centers of origin of $C$. annuum, where archaeobotanical traces date back from 600 to 1521 B.C.

${ }^{1}$ Centro Interdisciplinario de Investigación para el Desarrollo Integral Regional-Unidad Oaxaca, Instituto Politécnico Nacional, Hornos $\mathrm{N}^{\circ}$ 1003, Col. Nochebuena, Santa Cruz Xoxocotlan, Oaxaca, México. C.P. 71230. "Corresponding author (jchavezservia@yahoo.com).

${ }_{2}^{2}$ Instituto Tecnológico del Valle de Oaxaca, Ex-Hacienda de Nazareno, Santa Cruz Xoxocotlan, Oaxaca, México. C.P. 71230.

${ }^{3}$ Centro de Investigación y de Estudios Avanzados, Unidad Irapuato km 9.6 Carr. Irapuato-León, Irapuato, Guanajuato, México. C.P. 36500 .

Received: 5 January 2011.

Accepted: 25 August 2011.
Every year, in Mexico more than 140000 ha of fresh pepper are planted. In particular, the state of Oaxaca planted an area which accounts for almost 2200 ha, with an average yield of $5.1 \mathrm{t} \mathrm{ha}^{-1}$ (SIAP, 2009). LópezLópez (2007b), in a collection of 116 individual and population-based samples, determined by at least 22 different morphotypes or landraces of regional peppers that were differentiated by fruit shapes, local names, and a high morphological variability of plant traits. In the last decade of pepper documented history in Oaxaca, 'Chile de Agua' (C. annuum) landrace has been the main focus of researchers, because of its popularity in the Central Valleys of Oaxaca (López-López, 2007a; Pablo et al., 2009; Vásquez et al., 2009), followed by 'Paradito' landrace, which has also been widely documented (LópezLópez, 2007b). The genebank of the Regional University Center of the Universidad Autonoma Chapingo has a collection of 304 accessions from Oaxaca (Córdova and Molina, 2006). Nevertheless, little is known about the composition of the fruits; neither the accession, nor the landraces of those which are cultivated and gathered in their native area of Oaxaca.

Carotenoid rich food consumption is directly related to a lower risk of cardiovascular disease and moreover some types of cancer (Pérez-Gálvez et al., 2003). Pepper fruit contains a broad variety of carotenoids, flavonoids, phenols, ascorbic acid, capsaicin, and other components, which determine the great variability of the fruit's smell, 
flavor, taste and consequently consumer preference. However, the fruit composition changes according to the ripeness stage (Navarro et al., 2006; Conforti et al., 2007; Deepa et al., 2007), and the environmental conditions in which the fruit was grown and in the case of cultivated varieties, the crop management (Medina-Lara et al., 2008; Monforte-González et al., 2010). Therefore, the purpose of this study was to evaluate the variation of phytochemical composition and the color of nine morphotypes of wild and cultivated peppers from Oaxaca, Mexico.

\section{METHODS AND MATERIALS}

\section{Plant material and samples preparation}

A sample of nine regional landraces or morphotypes of pepper: 'Chile de Agua', 'Güero', 'Nanchita', 'Piquín', 'Solterito', 'Tusta', 'Costeño', 'Canario', and 'Tabaquero', were collected from backyards and local markets in Valles Centrales, Sierra Sur, and Istmo regions of Oaxaca State, Mexico (Table 1). Morphotypes were determined according to fruit traits and classification proposed by López-López (2007a; 2007b) and Aguilar et al. (2010).

Each sample was composed of 250 to $750 \mathrm{~g}$ of immature pods completely developed, but not colored (commercial or consumption maturity), defined in local terms as light green for 'Chile de Agua' and 'Güero', greenish yellow for 'Tusta' and 'Güero', dark green for 'Nanchita', 'Piquín', 'Solterito', Tabaquero', and 'Canario'. The definition of unripe (immature, green) and ripe (mature red or yellow) was based on the criteria described by Howard et al. (2000) and Conforti et al. (2007). A sample corresponded to a lot of immature pods harvested from one plant found in the backyard or a pods lot purchased from just one seller, thereby avoiding a mixture of lots. All samples were matured (pods completely red or yellow) at room temperature during no more than $8 \mathrm{~d}$ without losing less than $80 \%$ of the pods humidity, according to the results of Krajayklang et al. (2000). In the maturation process, not all of the pods of the samples of 'Guero' and 'Tusta' reached the maturity stage (red), and just one part of the pods of 'Tabaquero', 'Solterito', 'Piquin', 'Nanchita' and 'Chile de Agua' reached maturity. On the basis of a limited sample size, the laboratory analyses were focused on the most common stages of consumption for each morphotype. For example, the consumption of immature pods (unripe) of 'Chile de Agua', 'Güero', 'Nanchita', 'Solterito', 'Tusta', and the mature (ripe) and/or immature in 'Tabaquero', 'Piquín', 'Costeño' and 'Canario' (Aguilar et al., 2010). The final pod lots analyzed were considered as randomized samples of the landrace diversity of pepper grown in Oaxaca, Mexico.

\section{Color, vitamin $\mathbf{C}$, total phenols and flavonoids}

Color in fresh fruits was measured in the mid-part of a random sample of nine pods by a portable Mini Scan photo-colorimeter (model MS/B-200S; Hunter Lab®, Reston, Virginia, USA) using the CIE Lab coordinates $\mathrm{L}^{*}, \mathrm{a}^{*}$ and $\mathrm{b}^{*}$; whereby $\mathrm{L}^{*}$ values indicate brightness or luminosity ( 0 , white to 100 , black); $a^{*}$ is defined as the variation from green (-) to red (+); while $b^{*}$ is defined as the variation from blue (-) to yellow $(+)$. With $\mathrm{L}^{*}, \mathrm{a}^{*}$ and $\mathrm{b}^{*}$ coordinates were calculated the chroma $\left(\mathrm{C}^{*}\right)=\left[\left(\mathrm{a}^{*}\right)^{2}+\right.$ $\left.\left(b^{*}\right)^{2}\right]^{1 / 2}$ and hue angle $\left(h^{\circ}\right)=\tan ^{-1}\left(b^{*} / a^{*}\right)$ values, according to McGuire (1992).

Vitamin C content in fresh fruits was determined by Durust et al. (1997) method. Samples were ground with oxalic acid at $0.4 \%$ in a ratio of $1: 10 \mathrm{w} / \mathrm{v}$ and put in a dark room for $20 \mathrm{~min}$ before its centrifugation at 660 rpm. Later, $1 \mathrm{~mL}$ of the supernatant was mixed with sodium acetate buffer solution and a 2,6-dichlorophenol indophenol solution. Then, absorbance of the solution was measured by spectrophotometer at a wavelength of $520 \mathrm{~nm}$, and the vitamin $\mathrm{C}$ was calculated on the basis of an adjusted calibration curve of L-ascorbic acid standard (99\% purity; Reg. 84272 Sigma, St. Louis, Missouri, USA). The estimated concentration of vitamin $\mathrm{C}$ was reported as ascorbic acid $\mathrm{mg} 100 \mathrm{~g}^{-1}$ fresh weight.

Total phenolic contents were determined by the FolinCiocalteu method proposed by Lin and Tang (2007). A

Table 1. List of plant material used in the phytochemical analysis of fruits.

\begin{tabular}{|c|c|c|c|c|c|}
\hline $\begin{array}{l}\text { Sample } \\
\text { number }\end{array}$ & $\begin{array}{l}\text { Local } \\
\text { name }\end{array}$ & $\begin{array}{l}\text { Location of sample collection } \\
\text { in Oaxaca, Mexico }\end{array}$ & $\begin{array}{l}\text { Altitude } \\
(\mathrm{m})\end{array}$ & Latitude & Longitude \\
\hline C-01 & Solterito or Paradito ${ }^{1}$ & Villa de Zaachila & 1520 & $16^{\circ} 56^{\prime} \mathrm{N}$ & $96^{\circ} 45^{\prime} \mathrm{W}$ \\
\hline $\mathrm{C}-02$ & Nanchita $^{1}$ & Villa de Zaachila & 1520 & $16^{\circ} 56^{\prime} \mathrm{N}$ & $96^{\circ} 45^{\prime} \mathrm{W}$ \\
\hline C-03 & Piquín ${ }^{1}$ & Villa de Zaachila & 1520 & $16^{\circ} 56^{\prime} \mathrm{N}$ & $96^{\circ} 45^{\prime} \mathrm{W}$ \\
\hline C-04 & Chile de Agua $^{1}$ & Villa de Zaachila & 1520 & $16^{\circ} 56^{\prime} \mathrm{N}$ & $96^{\circ} 45^{\prime} \mathrm{W}$ \\
\hline C-05 & Tusta $^{1}$ & Miahuatlán de Porfirio Díaz & 1600 & $16^{\circ} 19^{\prime} \mathrm{N}$ & $96^{\circ} 35^{\prime} \mathrm{W}$ \\
\hline C-06 & Tusta $^{1}$ & Miahuatlán de Porfirio Díaz & 1600 & $16^{\circ} 19^{\prime} \mathrm{N}$ & $96^{\circ} 35^{\prime} \mathrm{W}$ \\
\hline C-08 & Costeño ${ }^{1}$ & San Pedro Amuzgos & 520 & $16^{\circ} 39^{\prime} \mathrm{N}$ & $98^{\circ} 05^{\prime} \mathrm{W}$ \\
\hline C-09 & Costeño ${ }^{1}$ & San Isidro Amatitlán, Santa María Zacatepec & 320 & $16^{\circ} 45^{\prime} \mathrm{N}$ & $97^{\circ} 59^{\prime} \mathrm{W}$ \\
\hline C-10 & Costeño ${ }^{1}$ & San Antonio Zaragoza, Santa María Zacatepec & 310 & $16^{\circ} 45^{\prime} \mathrm{N}$ & $97^{\circ} 59^{\prime} \mathrm{W}$ \\
\hline C-11 & Costeño ${ }^{1}$ & Guadalupe, Santa María Zacatepec & 1412 & $16^{\circ} 45^{\prime} \mathrm{N}$ & $97^{\circ} 59^{\prime} \mathrm{W}$ \\
\hline C-12 & Canario $^{2}$ & San Juan Achiutla & 2000 & $17^{\circ} 18^{\prime} \mathrm{N}$ & $97^{\circ} 29^{\prime} \mathrm{W}$ \\
\hline C-13 & Canario $^{2}$ & San Francisco Chindua & 2120 & $17^{\circ} 25^{\prime} \mathrm{N}$ & $97^{\circ} 19^{\prime} \mathrm{W}$ \\
\hline C-14 & Tabaquero $^{1}$ & Linda Vista Montenegro, Santiago Jocotepec & 100 & $17^{\circ} 35^{\prime} \mathrm{N}$ & $95^{\circ} 53^{\prime} \mathrm{W}$ \\
\hline C-15 & Güero $^{1}$ & Miahuatlán de Porfirio Díaz & 1600 & $16^{\circ} 19^{\prime} \mathrm{N}$ & $96^{\circ} 35^{\prime} \mathrm{W}$ \\
\hline
\end{tabular}

${ }^{1}$ Capsicum annuum; ${ }^{2}$ Capsicum pubescens. 
fresh fruit sample without seeds was sliced and stored at $-20^{\circ} \mathrm{C}$ for $16 \mathrm{~h}$, before grinding it in a stainless steel blender for $30 \mathrm{~s}$. The extraction used deionized water in a ratio of $1: 10$, in an ice bath with a stirring mechanism for $15 \mathrm{~min}$. The homogenate was centrifuged at $3640 \mathrm{rpm}$. In order to measure the phenolic content, $0.1 \mathrm{~mL}$ of the supernatant it was mixed with $2.8 \mathrm{~mL}$ of deionized water, $2.0 \mathrm{~mL}$ of $2 \%$ sodium carbonate $\left(\mathrm{Na}_{2} \mathrm{CO}_{3}\right)$, and $0.1 \mathrm{~mL}$ of FolinCiocalteau reagents. After incubation at room temperature for $30 \mathrm{~min}$, the absorbance of the reaction mixture was measured at $750 \mathrm{~nm}$ on a UV-visible spectrophotometer (UV-1601; Shimadzu®, Kyoto, Japan) and compared with the absorbance of the control of deionized water. Gallic acid (3,4,5-trihydroxybenzoic acid with 97.5\% purity; Reg. 2050271 Sigma, St. Louis, Missouri, USA) was chosen as a standard. The calculation of total phenol content was based on the calibration curve of the gallic acid standard and the data was expressed as milligram gallic acid equivalents (GAE) $100 \mathrm{~g}^{-1}$ fresh weight.

The total flavonoid content was determined according to the aluminum chloride colorimetric method (Lin and Tang, 2007). From the homogenate, $0.5 \mathrm{~mL}$ of supernatant was mixed with $1.5 \mathrm{~mL}$ of $95 \%$ alcohol, $0.1 \mathrm{~mL}$ of $10 \%$ aluminum chloride hexahydrate $\left(\mathrm{AlCL}_{3}\right), 0.1 \mathrm{~mL}$ of $1 \mathrm{M}$ potassium acetate $\left(\mathrm{CH}_{3} \mathrm{COOK}\right)$ and $2.8 \mathrm{~mL}$ of deionized water reagents. After incubation at room temperature for 40 min, the absorbance of the reaction mixture was measured at $415 \mathrm{~nm}$ on a UV-visible spectrophotometer (model UV1601; Shimadzu ${ }^{\circledR}$, Kyoto, Japan) and compared with the absorbance of deionized water as the control. Flavonoid contents were calculated on the basis of the calibration curve of quercetin standard (2-(3,4-dihydroxyphenyl)3,5,7-trihydroxy-4H-1-benzopyran-4-one with 98\% purity; Reg. 317313 Sigma, St. Louis, Missouri, USA). Data was expressed as milligrams quercetin equivalents (QE) $100 \mathrm{~g}^{-1}$ fresh weight.

\section{$\boldsymbol{\beta}$-Carotene and capsaicinoids}

$\beta$-Carotene was measured according to the method suggested by Davis et al. (2003). The $\beta$-carotene analysis was carried out only on the samples of ripened pods that had reached maturity before $8 \mathrm{~d}$ at room temperature; 'Chile de Agua', 'Canario', 'Costeño', 'Piquin', and 'Tabaquero'. Once the pods had matured, the samples were ground using an extraction mix compound of ethanol, acetone and hexane in a ratio of 1:1:2 v/v. The ground sample was left in an ice bath with a stirring mechanism; distilled water was added and it was left to rest at room temperature, but the sample was protected from the light. An aliquot of the upper phase was taken to prepare a hexane-based dilution. The solution absorbance was measured with a UV/vis spectrophotometer at $446 \mathrm{~nm}$. The quantity of $\beta$-carotene in the sample was calculated using its data absorbance and the absorbance reading from the calibration curve of $\beta$-carotene standard $(\beta, \beta$-carotene with $97.0 \%$ purity, Reg. 18174416; Fluka,
Buchs SG, Switzerland). The $\beta$-carotene concentration was expressed as mg $100 \mathrm{~g}^{-1}$ fresh weight.

Capsaicin and dihydrocapsaicin determination was made by using gas chromatography (GC) (AbrahamJuárez et al., 2008). Whole fruits were dried in an oven with an air circulation ( $2 \mathrm{~mL} \mathrm{~min}^{-1}$ flow rate) of 58 to 60 ${ }^{\circ} \mathrm{C}$ for 2 to $3 \mathrm{~d}$ or until a constant weight was reached. The numbers of pepper used for each sample varied from $3>$ 20 depending on the peppers and how many were required to produce at least $10 \mathrm{~g}$ (air-dried tissue) of sample. The fruits were then ground and placed inside amber plastic flasks to be stored at $20{ }^{\circ} \mathrm{C}$ until the analysis was made (Cázares-Sánchez et al., 2005). The capsaicinoids were extracted from $20 \mathrm{mg}$ of the ground sample in $1 \mathrm{~mL}$ of $95 \%$ ethanol and heated at $70{ }^{\circ} \mathrm{C}$ for $4 \mathrm{~h}$. The suspended material was centrifuged at $2500 \mathrm{rpm}$ for $15 \mathrm{~min}$, and the supernatant was transferred to a vial. The sample was conserved at $-20{ }^{\circ} \mathrm{C}$ until further analysis.

Capsaicin and dihydrocapsaicin analysis were performed using a gas chromatograph (model Autosystem XL; Perkin Elmer ${ }^{\circledR}$, Norwalk, Connecticut, USA) with a capillary column (HP-5MS crosslinked 5\% phenyl, 95\% dimethylpolysiloxane; ID $0.25 \mathrm{~mm}$, length $30 \mathrm{~m}$, and film thickness $0.25 \mu \mathrm{m}$, Agilent, USA). Two-microliter samples of the extracts were injected directly into the GC and then the data was recorded. The column temperature program was as follows: $220{ }^{\circ} \mathrm{C}$ for $0 \mathrm{~min}, 3{ }^{\circ} \mathrm{C} \mathrm{min}-1$ to $270^{\circ} \mathrm{C}$ for $20 \mathrm{~min}$. The carrier gas was helium with a flow rate of $0.80 \mathrm{~mL} \mathrm{~min}{ }^{-1}$. Injector temperature was held at $260{ }^{\circ} \mathrm{C}$ during the analysis and the detector's temperature (FID) of $300{ }^{\circ} \mathrm{C}$. Capsaicin and dihydrocapsaicin contents were estimated on the basis of the external standard method which was defined with capsaicin (8-methylN-vanillyl-trans-6-nonenamide of capsicum with $95 \%$ purity; Reg. 2816484 Sigma, St. Louis, Missouri, USA) and dihydrocapsaicin (8-methyl-N-vanillylnonanamide of capsicum with 90\% purity; Reg. 2815150 Sigma, St. Louis, Missouri, USA) calibration curves. All analyses were made with three replicates.

\section{Statistical analysis}

Before making a statistical analysis all of the data that was obtained, it was transformed using $\sqrt{ } \mathrm{X}$ expression except for the chromatic coordinate $\mathrm{a}^{*}$ values and the hue angle, which were transformed by $\sqrt{X}+20$ due to the presence of negative values, and the chroma $\left(\mathrm{C}^{*}\right)$ percentages were transformed by $\arcsin \sqrt{ }(\mathrm{X} / 100)$. For the statistical analysis, the chromatic coordinates, hue angle and chroma were considered as independent transformed variables. Then, an ANOVA was performed on each variable using a lineal model of completely random design (unbalanced number of observations/replicates per sample evaluated) where landraces or morphotypes were considered as a random effect and the ripeness stage as a nested effect within the morphotypes (Steel and Torrie, 1985). A Tukey's multiple comparison test $(p \leq 0.05)$ 
was carried out when differences were found between the morphotypes and the ripeness stages. In order to determine the relationship between chemical compounds and color coordinates, a Pearson's correlation analysis was made (Student test, $P \leq 0.05$ ). All data analysis was done using SAS software (SAS Institute, 1999).

\section{RESULTS AND DISCUSSION}

Mean squares resulting from ANOVA for all phytochemical variables, color coordinates, and parameters showed significant differences among morphotypes and ripeness stages, except for vitamin $\mathrm{C}$ in ripeness stages. A high variability of carotenoids, flavonoids and vitamin $\mathrm{C}$ content was found, with variation coefficients of 25.2 to $37.8 \%$ (Table 2). The estimated variability suggests that

Table 2. Significance of the mean squares resulting from the variance analysis of phytochemical compounds and color chromatic coordinates in nine pepper morphotypes.

\begin{tabular}{lccr}
\hline Variables & $\begin{array}{c}\text { Mean squares } \\
\text { of morphotypes }\end{array}$ & $\begin{array}{c}\text { Mean squares of } \\
\text { ripeness stages }\end{array}$ & $\begin{array}{c}\mathrm{CV} \\
(\%)\end{array}$ \\
\hline Vitamin C & $80.87 * *$ & $12.38^{\mathrm{NS}}$ & 26.4 \\
Phenols & $30.91 * *$ & $92.44 * *$ & 15.4 \\
Flavonoids & $23.67 * *$ & $26.42^{* *}$ & 25.2 \\
$\beta$-carotene & $69.39 * *$ & & 37.8 \\
$\mathrm{~L}^{*}$ & $4.13^{* *}$ & $1.43^{* *}$ & 10.1 \\
$\mathrm{a} *$ & $1.51 * *$ & $38.69^{* *}$ & 6.7 \\
$\mathrm{~b}^{*}$ & $4.11^{* *}$ & $1.89^{* *}$ & 9.8 \\
Hue angle $\left(\mathrm{h}^{\circ}\right)$ & $1.17 * *$ & $10.64 * *$ & 2.4 \\
Chroma $\left(\mathrm{C}^{*}\right)$ & $539.77^{* *}$ & $749.83^{* *}$ & 14.6 \\
Capsaicin & $62.10^{* *}$ & & 23.2 \\
Dihydrocapsaicin & $43.20^{* *}$ & & 25.3 \\
\hline Ns $=$ non significant at $\mathrm{p}>0.05 ; * *$ significant at $\mathrm{p} \leq 0.01 ; \mathrm{CV}=$ variation coefficient.
\end{tabular}

the samples evaluated showed very varied phenotypic expressions where the environmental effects of the place where plants grown and genotypic effects of the morphotypes are confused due to the fact that each sample was not related and was collected in different backyards or purchased with different market sellers.

\section{Phytochemical composition and color}

Mean values of vitamin $\mathrm{C}$, total phenols, flavonoids, $\beta$-carotene, color coordinates and parameters in the nine pepper morphotypes are shown in Table 3. Vitamin C (ascorbic acid concentration) varied greatly from sample to sample and within pepper types, with values ranging from 1.9 to 18.0 in 'Canario' (C. pubescens) to $183.2 \mathrm{mg}$ $100 \mathrm{~g}^{-1}$ in 'Tabaquero' ( $C$. annuum). The ascorbic acid variation presented three general patterns: 'Costeño', 'Guero' and 'Tabaquero' had the highest values, while 'Chile de Agua', 'Nanchita' and 'Solterito' had medium values, and 'Tusta', 'Piquín' and 'Canario' had the lowest values, showing part of the differences in fruit composition among landraces grown in Oaxaca, Mexico. As other studies have shown, the highest or the lowest values of vitamin $\mathrm{C}$ in $C$. annum are dependent on the varieties and the maturity stage of the fruits (Khadi et al., 1987; Howard et al., 2000). The vitamin C content found in this research was within reported ranges in other studies. For example, in the $C$. annuum pepper grown in Turkey, a variation that ranged from 15.2 to $64.9 \mathrm{mg}$ $100 \mathrm{~g}^{-1}$ fresh fruit was reported (Topuz and Ozdemir, 2007). And another study conducted in India with the same species showed a variation that ranged from 48.23

Table 3. Comparison of averages within and among pepper morphotypes by ripeness stage, in terms of phytochemical compounds and color chromatic coordinates.

\begin{tabular}{|c|c|c|c|c|c|c|c|c|c|}
\hline \multirow{2}{*}{$\begin{array}{l}\text { Morphotypes and } \\
\text { ripeness stage }\end{array}$} & \multirow[b]{2}{*}{ Vitamin C } & \multirow{2}{*}{$\begin{array}{c}\text { Total } \\
\text { phenols }\end{array}$} & \multirow{2}{*}{$\begin{array}{c}\text { Flavo- } \\
\text { noids }\end{array}$} & \multirow{2}{*}{$\begin{array}{l}\text { Carote- } \\
\text { noids }\end{array}$} & \multirow[b]{2}{*}{ Hue angle } & \multirow{2}{*}{$\begin{array}{c}\text { Chroma } \\
\left(\mathrm{C}^{*}\right)\end{array}$} & \multicolumn{3}{|c|}{ Chromatic coordinates } \\
\hline & & & & & & & $\mathrm{L}^{*}$ & $a^{*}$ & $\mathrm{~b}^{*}$ \\
\hline & 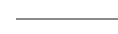 & $\mathrm{mg} 100 \mathrm{~g}^{-1}$ & - & & & & & & \\
\hline \multicolumn{10}{|l|}{ Tusta $^{1}$} \\
\hline Unripe & $41.5 \mathrm{a}^{3}$ & $186.4 \mathrm{bc}$ & $17.9 \mathrm{bc}$ & & $-84.3 b$ & $38.6 \mathrm{ab}$ & $72.1 \mathrm{ab}$ & $-3.7 c$ & $38.4 \mathrm{abc}$ \\
\hline \multicolumn{10}{|l|}{ Tabaquero $^{1}$} \\
\hline Ripe & LS & $69.7 \mathrm{~d}$ & $9.5 b c$ & $64.4 \mathrm{ab}$ & $44.4 \mathrm{a}$ & $56.0 \mathrm{a}$ & $32.3 \mathrm{~d}$ & $40.0 \mathrm{a}$ & $39.2 \mathrm{abc}$ \\
\hline Unripe & $183.2 \mathrm{a}$ & $402.2 \mathrm{a}$ & $26.4 b c$ & ND & $-74.0 \mathrm{~b}$ & $42.0 \mathrm{ab}$ & $39.9 \mathrm{~cd}$ & $-11.5 c$ & $40.4 \mathrm{abc}$ \\
\hline \multicolumn{10}{|l|}{ Solterito $^{1}$} \\
\hline Ripe & LS & LS & LS & & $37.3 \mathrm{a}$ & $38.7 \mathrm{ab}$ & $32.1 \mathrm{~d}$ & $30.8 \mathrm{ab}$ & $23.5 \mathrm{c}$ \\
\hline Unripe & $86.7 \mathrm{a}$ & $243.9 \mathrm{abc}$ & $63.4 \mathrm{ab}$ & & $-69.5 b$ & $8.4 \mathrm{~b}$ & $21.8 \mathrm{~d}$ & $-2.9 \mathrm{c}$ & $7.8 \mathrm{c}$ \\
\hline \multicolumn{10}{|l|}{ Piquín ${ }^{1}$} \\
\hline Ripe & LS & $309.5 \mathrm{ab}$ & $50.1 \mathrm{abc}$ & $132.9 \mathrm{a}$ & $45.0 \mathrm{a}$ & $54.4 \mathrm{a}$ & $32.6 \mathrm{~d}$ & $38.5 \mathrm{a}$ & $38.3 \mathrm{bc}$ \\
\hline Unripe & $29.1 \mathrm{a}$ & $215.6 \mathrm{bc}$ & $97.4 \mathrm{a}$ & ND & $-80.8 b$ & $41.0 \mathrm{ab}$ & $49.4 \mathrm{bcd}$ & $-6.4 c$ & $40.3 \mathrm{abc}$ \\
\hline \multicolumn{10}{|l|}{ Nanchita $^{1}$} \\
\hline Ripe & LS & LS & LS & & $38.8 \mathrm{a}$ & $43.0 \mathrm{ab}$ & $31.7 \mathrm{c}$ & $33.5 \mathrm{ab}$ & $27.0 \mathrm{bc}$ \\
\hline Unripe & $90.4 \mathrm{a}$ & $198.3 \mathrm{bc}$ & $34.0 \mathrm{bc}$ & & $-72.3 b$ & $45.5 \mathrm{ab}$ & 51.7abcd & $-13.8 \mathrm{c}$ & $43.4 \mathrm{abc}$ \\
\hline \multicolumn{10}{|l|}{ Güero $^{1}$} \\
\hline Unripe & $151.6 \mathrm{a}$ & $233.0 \mathrm{abc}$ & $33.3 \mathrm{bc}$ & & $-86.4 b$ & $56.2 \mathrm{a}$ & $74.6 a$ & $-3.4 c$ & $56.0 \mathrm{ab}$ \\
\hline \multicolumn{10}{|l|}{ Costeño $^{1}$} \\
\hline Ripe & $175.4 \mathrm{a}$ & $350.4 \mathrm{a}$ & $60.8 \mathrm{abc}$ & $29.3 \mathrm{bc}$ & $54.2 \mathrm{a}$ & $68.6 \mathrm{a}$ & $47.5 \mathrm{~cd}$ & $37.6 \mathrm{a}$ & $55.8 \mathrm{ab}$ \\
\hline Unripe & $119.2 \mathrm{a}$ & $175.5 b c$ & $14.9 \mathrm{bc}$ & ND & $-75.4 b$ & $49.0 \mathrm{a}$ & $45.7 \mathrm{~cd}$ & $-12.1 \mathrm{c}$ & $47.4 \mathrm{abc}$ \\
\hline \multicolumn{10}{|l|}{ Canario $^{2}$} \\
\hline Ripe & $18.0 \mathrm{a}$ & $112.7 \mathrm{c}$ & $6.4 \mathrm{c}$ & $3.4 \mathrm{c}$ & $68.4 \mathrm{a}$ & $60.9 \mathrm{a}$ & $52.8 \mathrm{abc}$ & $22.4 \mathrm{~b}$ & $56.5 \mathrm{a}$ \\
\hline Unripe & $1.9 \mathrm{a}$ & $113.8 \mathrm{c}$ & $13.1 \mathrm{bc}$ & ND & $-74.8 \mathrm{~b}$ & $35.4 \mathrm{ab}$ & $42.1 \mathrm{~cd}$ & $-9.2 \mathrm{c}$ & $34.1 \mathrm{bc}$ \\
\hline \multicolumn{10}{|l|}{ Chile de Agua ${ }^{1}$} \\
\hline Ripe & LS & LS & LS & $15.2 \mathrm{c}$ & $49.2 \mathrm{a}$ & $58.3 \mathrm{a}$ & $37.3 \mathrm{~cd}$ & $38.1 \mathrm{a}$ & $44.1 \mathrm{abc}$ \\
\hline Unripe & $90.1 \mathrm{a}$ & $180.4 b c$ & $44.4 \mathrm{ab}$ & ND & $-78.8 \mathrm{~b}$ & $56.8 \mathrm{a}$ & $52.0 \mathrm{abcd}$ & $-11.1 \mathrm{c}$ & $55.7 \mathrm{abc}$ \\
\hline
\end{tabular}

LS; limited sample; ND; non detected.

${ }^{1}$ Capsicum annuum; ${ }^{2}$ Capsicum pubescens; ${ }^{3}$ Means followed by the same letters are not significantly different (Tukey, $\mathrm{p} \leq 0.05$ ). 
to $192.63 \mathrm{mg} 100 \mathrm{~g}^{-1}$ as reported by Deepa et al. (2006). Nevertheless, differences were found in vitamin $C$ for $C$. pubescens within this study and the values reported by Cruz-Pérez et al. (2007), where vitamin C concentration rates varied from 238.35 to $455.4 \mathrm{mg} 100 \mathrm{~g}^{-1}$ fresh weight.

Among morphotypes, the total phenol and flavonoid values averaged from 113.2 to 262.9 and 9.7 to 73.7 mg $100 \mathrm{~g}^{-1}$ fresh weight, respectively. 'Canario' ( $C$. pubescens) presented the lowest values, in phenols as well as in flavonoids, which are the opposite to the values found in 'Piquin', 'Solterito' and 'Costeño', of $C$. annuum. Phenolic values found in this study are within the ranges reported by Marinova et al. (2005) and Lin and Tang (2007) for unripe and ripe $C$. annuum fruits

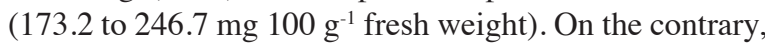
with respect to flavonoids, their values (4.1 to $27.4 \mathrm{mg}$ $100 \mathrm{~g}^{-1}$ fresh weight) were lower than the values found in this study for $C$. annuum morphotypes such as 'Chile de Agua', 'Costeño', 'Güero', 'Nanchita', 'Piquin' and 'Solterito' (33.2 to $73.7 \mathrm{mg} 100 \mathrm{~g}^{-1}$ ) (Table 3).

The results show an important difference between $C$. pubescens ('Canario') and C. annuum in total phenols and flavonoids but also within $C$. annuum morphotype ones. Nevertheless, the concentrations of flavonoids and phenols depend on cultivation, ripeness, storage and soil salinity, among other factors (Zhang and Hamauzu, 2003; Marinova et al., 2005; Navarro et al., 2006). In this research, the samples evaluated did not increase the phenol and flavonoid contents from unripe (green) to ripe (red or yellow) stage as was determined by Deepa et al. (2007) in C. annuum, probably due to there being no control over the maturation process, but the results were similar to those evaluated by Howard et al. (2000) in C. annuum.

All pigments responsible for the color of pepper fruits have characteristics of chromophores as a result of its conjugated double bonds system in its molecules. The color of the fruits at their ripe stage varied from yellow variants most likely produced by zeaxanthin, $\beta$-cryptoxanthin, and $\beta$-carotene to red induced by capsanthins and capsorubin depending on the length of the conjugated double bonds system and the presence of different functional groups (Hornero-Méndez and Minguez-Mosquera, 2001). This research measured $\beta$-carotene in ripe fruits; the highest values were calculated in 'Costeño', 'Tabaquero', and 'Piquin' (29.3 to $132.9 \mathrm{mg} 100 \mathrm{~g}^{-1}$ fresh weight) that matured to a red color, and also the results did not show substantial differences between 'Chile de agua' and 'Canario' (yellow) morphotypes (Table 3). Howard et al. (2000) found that the highest values of $\beta$-carotene in $C$. annuum and $C$. frutescens were determined by its maturity stage (33.7 to $118.7 \mathrm{mg} 100 \mathrm{~g}^{-1}$ fresh weight) but slightly less than the 'Piquin' type (132.9 mg $100 \mathrm{~g}^{-1}$ fresh weight). The data found on $\beta$-carotene content provides information on the variation in pigments in pepper landraces grown and consumed in Oaxaca.

Visual color was measured by coordinates CIE Lab L*, $\mathrm{a}^{*}$ and $\mathrm{b}^{*}$, and estimators Hue and chroma. The values of these coordinates varied greatly from sample to sample depending on the pepper type. 'Güero' morphotype presented the highest values of $\mathrm{L}^{*}$ and $\mathrm{b}^{*}$, as well as a negative value of $\mathrm{a}^{*}$, which is congruent since only unripe fruit (green-yellowish) were analyzed. Cultivated morphotype 'Tusta' presented a similar pattern to the 'Güero' type. These landraces have similar colors except that 'Tusta' has a rough epidermis while 'Güero's' skin is smooth (Table 3).

Regarding ripeness stages within each morphotype of pepper, the content of vitamin $\mathrm{C}$ did not present significant differences among and within morphotypes, which seems to indicate a low variability among samples. The results showed that 'Tabaquero' type has a higher phenolic content in the unripe stage (green) than in the ripe stage (red); 'Costeño' landrace showed the opposite pattern, having more phenols in the ripe stage (red and yellow) than in the unripe stage (green). 'Canario' $C$. pubescens) had the same quantity of phenols in the ripe stage (yellow) than in the unripe stage (green). Flavonoids varied among pepper types, but did not vary according to the different stages of ripeness (Table 3 ). These results suggest that there are differences in phenols and flavonoids among fruit types, with mixed pattern variations according to ripeness stages and pepper types.

With respect to chromatic coordinates, unripe fruits had negative values in $\mathrm{a}^{*}$, according to the different color intensity of green. 'Tabaquero', 'Nanchita', 'Costeño' and 'Chile de Agua' were greener fruits. On the other hand, redder or yellower ripe fruits ( $\mathrm{a}^{*}$ positive) were found in 'Tabaquero', 'Solterito', 'Piquín', 'Nanchita', 'Costeño' and 'Chile de Agua' (Table 3). Hue angle was useful to differentiate the unripened and ripe pods by its negative and positive values, respectively. In this work hue angle, chroma and CIE coordinated were useful to explain the differences in the skin color of the fruit among and within samples, and they proportioned complementary information such as was discussed by Kim et al. (2008) in C. annuum.

Table 4 shows the correlations between vitamin $\mathrm{C}$, phenols, flavonoids, $\beta$-carotene and color coordinates and parameters. For instance, $b^{*}$ coordinate and $C^{*}$ parameter showed significant correlations $(p<0.05)$ with every phytochemical compound, regardless of the ripeness stage. $\mathrm{L}^{*}, \mathrm{~b}^{*}, \mathrm{C}^{*}$, and hue angle had a negative correlation with $\beta$-carotene, meaning that the higher carotenoid content is related with low brightness and variations in the visual expression of the mature stage of the fruits. Coordinate $a^{*}$ showed a positive and significant correlation $(r=0.42)$ with flavonoids present in the fruit; that is, the fruit with a tendency towards red presented the higher flavonoid concentration. These relationships confirm part of the results shown in Table 3; flavonoid content increases, in certain pepper types, at ripe more than unripe stages and sometimes phenols follow the same pattern. 
Table 4. Pearson correlations (r) among vitamin C, total phenols, flavonoids, and $\beta$-carotene, and color chromatic coordinates in wild and cultivated peppers of Oaxaca.

\begin{tabular}{lccccc}
\hline \multirow{2}{*}{$\begin{array}{l}\text { Phytochemical } \\
\text { compounds }\end{array}$} & $\begin{array}{c}\text { Hue angle } \\
\left(\mathrm{h}^{\circ}\right)\end{array}$ & $\begin{array}{c}\text { Chroma } \\
\left(\mathrm{C}^{*}\right)\end{array}$ & \multicolumn{3}{c}{ Chromatic coordinates } \\
\cline { 5 - 6 } & $0.07^{\mathrm{NS}}$ & $0.38^{*}$ & $-0.09^{\mathrm{NS}}$ & $0.22^{\mathrm{NS}}$ & $0.30^{*}$ \\
Vitamin C & $0.23^{\mathrm{NS}}$ & $0.36^{*}$ & $<0.01^{\mathrm{NS}}$ & $0.28^{*}$ & $0.27^{*}$ \\
Phenols & $0.34^{*}$ & $0.41^{* *}$ & $-0.08^{\mathrm{NS}}$ & $0.42^{* *}$ & $0.28^{*}$ \\
Flavonoids & $-0.38^{*}$ & $-0.38^{*}$ & $-0.66^{* *}$ & $0.20^{\mathrm{NS}}$ & $-0.41^{* *}$ \\
$\beta$-carotene & & &
\end{tabular}

Ns: non significant at $\mathrm{p}>0.05 ; *$ : significant at $\mathrm{p}<0.05$; **: significant at $\mathrm{p}<0.01$ (Student test).

\section{Capsaicinoids}

Pungency or the hot taste of pepper fruits is attributed mainly to capsaicinoid concentration, which adds flavor to food when used as spices. These compounds are recognized for their therapeutic effects on gastric ulcers and rheumatoid arthritis (Matucci-Cerinic et al., 1990; Sathyanarayana, 2006). Capsaicinoids identified in Capsicum fruits are vanillylamides of branched fatty acids, with 9 to 11 carbons, of which capsaicin (vanillylamide of 8-methylnontrans-6-enoic acid) and dihydrocapsaicin (vanillylamide of 8 mehylnonanoic acid) are the most abundant capsaicinoids (Topuz and Ozdemir, 2007). In this study, capsaicin concentration (CAP) was higher than dihydrocapsaicin (DH) in all morphotypes, with the exception of 'Canario' ( $C$. pubescens), and it suggests a difference between $C$. annumm and $C$. pubescens (Table $5)$. However, the results show significant differences within C. annuum types; for example, type 'Chile de Agua' and 'Tabaquero' showed values of 4.9 and $6.7 \mu \mathrm{g} \mathrm{mL}$ '-1 contrasting with 'Piquin' and 'Solterito' that presented value of 116.2 to $142.0 \mu \mathrm{g} \mathrm{mL}^{-1}$ in capsaicin content. The same pattern was observed in dihydrocapsaicin.

The estimated pattern in CAP:DH ratio to C. annuum morphotypes was similar (except for the values) to the pattern determined by Cázares-Sánchez et al. (2005) and Morán-Bañuelos et al. (2008) in the same species, although in this work there were 1.9 to 6.5 units of capsaicin per every unit of dihydrocapsaicin. 'Piquin' and 'Solterito' showed the significantly highest capsaicin and dihydrocapsaicin values among the morphotypes and they can be considered the hottest peppers, according to consumer opinion; followed by 'Tusta', 'Canario'

Table 5. Averages and standard deviation of capsaicin and dihydrocapsaicin in ripe fruits of nine pepper morphotypes.

\begin{tabular}{|c|c|c|c|}
\hline Morphotypes & $\begin{array}{l}\text { Capsaicin } \\
\text { (CAP) }\end{array}$ & $\begin{array}{c}\text { Dihydrocapsaicin } \\
\text { (DH) }\end{array}$ & CAP:DH \\
\hline & \multicolumn{2}{|c|}{$\longrightarrow \mu \mathrm{g} \mathrm{mL}^{-1} \longrightarrow$} & \\
\hline Chile de Agua ${ }^{1}$ & $4.9 \mathrm{~d}^{4}( \pm 1.5)$ & $1.6 \mathrm{e}( \pm 0.7)$ & $3.1: 1.0$ \\
\hline Canario $^{2}$ & $15.2 \mathrm{~cd}( \pm 6.0)$ & $33.0 \mathrm{~b}( \pm 9.9)$ & $1.0: 2.2$ \\
\hline Costeño $^{1}$ & $14.6 \mathrm{~cd}( \pm 12.6)$ & $4.0 \mathrm{de}( \pm 3.4)$ & $3.6: 1.0$ \\
\hline Güero $^{1,3}$ & $44.5 \mathrm{~b}( \pm 9.2)$ & $6.8 \mathrm{de}( \pm 0.9)$ & $6.5: 1.0$ \\
\hline Nanchita $^{1}$ & $27.4 \mathrm{bc}( \pm 7.7)$ & $13.2 \mathrm{~cd}( \pm 4.7)$ & $2.1: 1.0$ \\
\hline Piquín ${ }^{1}$ & $116.2 \mathrm{a}( \pm 24.5)$ & $62.4 \mathrm{a}( \pm 18.3)$ & $1.9: 1.0$ \\
\hline Solterito $^{1}$ & $142.0 \mathrm{a}( \pm 2.9)$ & $65.5 \mathrm{a}( \pm 3.7)$ & $2.2: 1.0$ \\
\hline Tabaquero $^{1}$ & $6.7 \mathrm{~d}( \pm 1.8)$ & $1.5 \mathrm{e}( \pm 0.3)$ & $4.5: 1.0$ \\
\hline Tusta $^{1,3}$ & $51.4 \mathrm{~b}( \pm 24.5)$ & $33.5 \mathrm{bc}( \pm 15.1)$ & $1.5: 1.0$ \\
\hline
\end{tabular}

${ }^{1}$ Capsicum annuum $;{ }^{2}$ Capsicum pubescens; ${ }^{3}$ It was only measured in unripe stage.

${ }^{4}$ Means followed by the same letters are not significantly different (Tukey, $\mathrm{p}<0.05$ ); \pm standard deviation. and 'Nanchita' (Table 5). Results indicate that pepper morphotypes may differ in their content of capsaicinoids and dihydrocapsaicinoids, which are responsible for the typical hot taste, sometimes preferred by consumers. That is why these peppers are still preserved in local communities, arable lands and adjacent areas where wild peppers like 'Piquin', 'Tabaquero', 'Nanchita' and 'Solterito' grow without any human intervention.

\section{CONCLUSIONS}

Different fruit composition of the nine pepper morphotypes indicates that apart from the evident morphological differences in terms of fruit shape and appearance, they also differ in their content of vitamin $\mathrm{C}$, phenols, flavonoids, $\beta$-carotene, chromatic coordinates coloring CIE, hue angle, capsaicin and dihydrocapsaicin, depending on the ripeness stage. The highest values of vitamin $\mathrm{C}$ are found in 'Tabaquero', 'Güero' and 'Costeño' morphotypes and the highest values of phenols and flavonoids were found in 'Piquin' and 'Solterito' morphotypes. $\beta$-Carotene ranged from 3.4 to $132.9 \mathrm{mg} 100 \mathrm{~g}^{-1}$ in ripe fresh fruit samples. Coordinates $\mathrm{a}^{*}$ and $\mathrm{b} *$ and chroma had a positive correlation with the content of phenols and flavonoids; whereas $\beta$-carotene showed a negative correlation with $\mathrm{L}^{*}, \mathrm{~b}^{*}$, hue angle and chroma. Pepper morphotypes analyzed in this study presented significant differences in capsaicinoid and dihydrocapsaicinoid content. Capsicum aпnиит was higher in capsaicin than in dihydrocapsaicin; while $C$. pubescens showed the opposite pattern.

\section{ACKNOWLEDGEMENTS}

We would like to thank Instituto Politécnico NacionalMéxico for their supporting this project with funds SIP20090175 and SIP-20100026.

Evaluación fitoquímica en chile (Capsicum annuum $\mathrm{L}$. and $C$. pubescens Ruiz \& Pav.) silvestre y cultivado en Oaxaca, México. En la última década, se reportó que el consumo de ciertos alimentos y especias, como el chile (Capsicum annuum L.), pueden tener un efecto positivo en la salud. Particularmente, los acervos genéticos mexicanos de chile están poco documentados en relación a la diversidad desde la perspectiva fitoquímica. En este trabajo se evaluó la variación de compuestos fitoquímicos en nueve morfotipos de chile silvestres y cultivados de Oaxaca. El ANDEVA detectó diferencias significativas entre morfotipos y estados de madurez en vitamina $\mathrm{C}$, fenoles, flavonoides, $\beta$-caroteno, color, y capsaicinoides. Los valores más altos de vitamina $\mathrm{C}$ se determinaron en 'Tabaquero', 'Güero' y 'Costeño' (151.6 a 183.2 mg $\left.100 \mathrm{~g}^{-1}\right)$. En fenoles y flavonoides sobresalieron los tipos 'Piquín' y 'Solterito'. Las coordenadas cromáticas a* y $\mathrm{b}^{*}, \mathrm{y}$ los tonos $\left(\mathrm{C}^{*}\right)$ se correlacionaron positivamente con el contenido de fenoles totales y flavonoides. 
Los morfotipos evaluados difieren en el contenido de capsaicina y dihidrocapsaicina, en $C$. annuum fue mayor la cantidad de capsaicina (4.9 a $142 \mu \mathrm{g} \mathrm{mL}^{-1}$ ) que de dihidrocapsaicina (1.5 a $\left.65.5 \mu \mathrm{g} \mathrm{mL}^{-1}\right)$ y en $C$. pubescens Ruiz \& Pav. el patrón fue inverso.

Palabras clave: capsaicionoides, Capsicum annuum, carotenoides, fenoles, flavonoides, vitamina $\mathrm{C}$.

\section{LITERATURE CITED}

Abraham-Juárez, M.R., M.C. Rocha-Granados, M.G. López, R.F. Rivera-Bustamante, and N. Ochoa-Alejo. 2008. Virus-induced silencing of Comt, pAmt and Kas genes results in a reduction of capsaicinoid accumulation in chili pepper fruits. Planta 227:681695.

Aguilar, V.H., T. Corona, P. López, L. Latournerie, M. Ramírez, H. Villalón, y J. A. Aguilar. 2010. Los chiles de México y su distribución. 114 p. SINAREFI, Colegio de Postgraduados, INIFAP. IT-Conkal, UANL, UAN. Texcoco, México.

Cázares-Sánchez, E., P. Ramírez-Vallejo, F. Castillo-González, R.M. Soto-Hernández, M.T. Rodríguez-González, y J.L. ChávezServia. 2005. Capsaicinoides y preferencias de uso en diferentes morfotipos de chile (Capsicum annuиm L.) del centro-oriente de Yucatán. Agrociencia 39:627-638.

Conforti, F., G.A. Statti, and F. Menichini. 2007. Chemical and biological variability of hot pepper fruits (Capsicum annuиm var. acuminatum L.) in relation to maturity stage. Food Chemistry 102:1096-1104.

Córdova, T.L., y J.C. Molina. 2006. Conservación ex situ. p. 59-100. In Molina, J.C., y T.L. Córdova (eds.) Recursos fitogenéticos en México para la alimentación y la agricultura-informe nacional 2006. Secretaria de Agricultura, Ganadería, Desarrollo Rural, Pesca y Alimentación y Sociedad Mexicana de Fitogenética, A.C., Chapingo, México.

Cruz-Pérez, A.B., V.A. González-Hernández, R.M. Soto-Hernández, M.A. Gutiérrez-Espinoza, A.A. Gardea-Béjar, y M. PérezGrajales. 2007. Capsaicinoides, vitamina $C$ y heterosis durante el desarrollo del fruto de chile manzano. Agrociencia 41:627-635.

Davis, A.R., W.W. Fish, and P. Perkins-Veazie. 2003. A rapid spectrophotometric method for analyzing lycopene content in tomato and tomato products. Postharvest Biology and Technology 28:425-430.

Deepa, N., C. Kaur, B. George, B. Singh, and H.C. Kapoor. 2007. Antioxidant constituents in some sweet pepper (Capsicum annuиm L.) genotypes during maturity. Food Science and Technology 40:121-129.

Deepa, N., C. Kaur, B. Singh, and H.C. Kapoor. 2006. Antioxidant activity in some red sweet pepper cultivars. Journal of Food Composition and Analysis 19:572-578.

Durust, N., D. Sumengen, and Y. Durust. 1997. Ascorbic acid and element contents of foods of Trabzon (Turkey). Journal of Agricultural and Food Chemistry 45:2085-2087.

Eshbaugh, W.H. 1980. The taxonomy of the genus Capsicum (Solanaceae). Phytologia 47:153-166.

Hernández-Verdugo, S., R. Luna-Reyes, and K. Oayama. 2001. Genetic structure and differentiation of wild and domesticated populations of Capsicum annuиm (Solanaceae) from Mexico. Plant Systematics and Evolution 226:129-142.

Hornero-Méndez, D., and M.I. Minguez-Mosquera. 2001. Rapid spectrophotometric determination of red and yellow isochromic carotenoid fractions in paprika and red pepper oleoresins. Journal of Agricultural and Food Chemistry 49:3584-3588

Howard, L.R., S.T. Talcott, C.H. Brenes, and B. Villalon. 2000 Changes in phytochemical and antioxidant activity of selected pepper cultivar (Capsicum species) as influenced by maturity. Journal of Agricultural Food Chemistry 48:1713-1720.
Khadi, B.M., J.V. Goud, and V.B. Patil. 1987. Variation in ascorbic acid and mineral content in fruits of some varieties of chilli (Caspsicum annuum L.). Plant Foods for Human Nutrition 37:915.

Kim, S., T.Y. Ha, and J. Park. 2008. Characteristics of pigment composition and colour value by the difference of harvesting times in Korean red pepper varieties (Capsicum annuиm L.) International Journal of Food Science and Technology 43:915920

Krajayklang, M., A. Klieber, and P.R. Dry. 2000. Colour at harvest and post-harvest behaviour influence paprika and chilli spice quality. Postharvest Biology and Technology 20:269-278.

Lin, J.Y., and C.Y. Tang. 2007. Determination of total phenolic and flavonoid contents in selected fruits and vegetables, as well as their stimulatory effects on mouse splenocyte proliferation. Food Chemistry 101:140-147.

López-López, P. 2007a. El chile de agua: un chile típico de los Valles Centrales de Oaxaca. Revista Agroproduce (Mexico) 16:8-12.

López-López, P. 2007b. La diversidad genética del chile (Capsicum spp.) en Oaxaca, México. Revista Agroproduce (Mexico) 16:5-7.

Marinova, D., F. Ribarova, and M. Atanassova. 2005. Total phenolics and total flavonoids in Bulgarian fruits and vegetables. Journal of the University of Chemical Technology and Metallurgy 40:255260.

Matucci-Cerinic, M., S. Maribini, S. Jantsch, M. Cagnoni, and G. Partsch. 1990. Effects of capsaicin on the metabolism of rheumatoid arthritis synoviocytes in vitro. Annals of the Rheumatic Diseases 49:598-602.

McGuire, R.G. 1992. Reporting of objective color measurements HortScience 27:1254-1255.

Medina-Lara, F., I. Echevarría-Machado, R. Pacheco-Arjona, N Ruiz-Lau, A. Guzmán-Antonio, and M. Martínez-Estevez. 2008. Influence of nitrogen and potassium fertilization on fruiting and capsaicin content in Habanero pepper (Capsicum chinense Jacq.) HortScience 43:1549-1554.

Monforte-Gonzaléz, M., A. Guzmán-Antonio, F. Uuh-Chim, and F. Vázquez-Flota. 2010. Capsaicin accumulation is related to nitrate content in placentas of habanero peppers (Capsicum chinense Jacq.). Journal of the Science of Food and Agriculture 90:764768

Morán-Bañuelos, S.H., V.H. Aguilar-Rincón, T. Corona-Torres, F. Castillo-González, R.M. Soto-Hernández, y R. San MiguelChávez. 2008. Capsaicinoides en chiles nativos de Puebla, México. Agrociencia 42:807-816.

Muñoz, P.I., y B.C. Pinto. 1966. Taxonomía y distribución geográfica de los chiles cultivados en México. Folleto Misceláneo $\mathrm{N}^{\mathrm{o}} 15.50$ p. INIA-SAG, México, D.F., México.

Navarro, J.M., P. Flores, C. Garrido, and V. Martínez. 2006. Changes in the contents of antioxidant compounds in pepper fruits at different ripening stages, as affected by salinity. Food Chemistry 96:66-73.

Pablo, E., J.A. Mejía, A. Carballo, G. García, V.H. Aguilar, y T. Corona. 2009. Calidad de semilla en colectas de chile de agua (Capsicum annuum L.) de los Valles Centrales, Oaxaca, México. Agricultura Técnica en México 35:257-266.

Pérez-Gálvez, A., H.D. Martín, H. Sies, and W. Stahl. 2003. Incorporation of carotenoids from paprika oleoresin into human chylomicrons. British Journal of Nutrition 89:787-793.

Perry, L., and K.V. Flannery. 2007. Precolumbian use of chili peppers in the Valley of Oaxaca, Mexico. Proceedings of the National Academy of Science of the United States of America 104:1190511909.

SAS Institute. 1999. STAT Guide for personal computers. 1643 p. $8^{\text {th }}$ ed. SAS Institute, Cary, North Carolina, USA.

Steel, R.G.D., y J.H. Torrie. 1985. Bioestadística: principios y procedimientos. 622 p. McGraw-Hill Latinoamericana, Bogotá, Colombia.

Sathyanarayana, M.N. 2006. Capsaicin and gastric ulcers. Critical Reviews of Foods Science and Nutrition 46:275-328.

SIAP. 2009. Anuario estadístico de la producción agrícola 2008 
Servicio de Información Agroalimentaria y Pesquera (SIAP), México D.F. Available at http://www.siap.gob.mx/index. php?option $=$ com_content $\&$ view $=$ article $\&$ id $=10 \&$ Itemid $=15$ (accessed 2 September 2010).

Smith, P.G., and C.B. Heiser. 1957. Taxonomy of Capscium sinense Jacq. and the geographic distribution on the cultivated Capsicum species. Bulletin of the Torrey Botanical Club 84:413-420.

Topuz, A., and F. Ozdemir. 2007. Assessment of carotenoids, capsaicinoids and ascorbic acid composition of some selected pepper cultivars (Capsicum annuиm L.) grown in Turkey. Journal of Food Composition and Analysis 20:596-602.
Vásquez, A., B. Tlapa, M.J. Yánez, R. Pérez, y M. Quintos. 2009. Etiología de la marchitez del 'chile de agua' (Capsicum annuum L.) en Oaxaca, México. Revista Fitotecnia Mexicana 23:127-134. Vela, E. 2009. El chile: una breve historia. Arqueología Mexicana 32 (especial):7-27.

Votava, E.J., G.P. Nabhan, and P.W. Bosland. 2002. Genetic diversity and similarity revealed via molecular analysis among and within an in situ population and ex situ accessions of chiltepín (Capsicum annuum var. glabriusculum). Conservation Genetics 3:123-129.

Zhang, D., and Y. Hamauzu. 2003. Phenolic compounds, ascorbic acid, carotenoids and antioxidant properties of green, red and yellow bell peppers. Food, Agriculture and Environment 2:22-27. 